\title{
THIRD WORLD APPROACHES TO DEVELOPMENT ECONOMICS - CRITIQUING EUROCENTRIC THEORETICAL MODELS IN SOUTH ASIAN CONTEXTS
}

\author{
Adhiraj Chhina \\ The British School, New Delhi \\ DOI: 10.46609/IJSSER.2020.v05i06.020 URL: https://doi.org/10.46609/IJSSER.2020.v05i06.020
}

\begin{abstract}
Development economics as a discipline has influenced the institutions which have fundamentally shaped policy globally, and charted solutions for economic growth. However, it is problematic that the theoretical foundations of this branch of economics originated from and continues to be Eurocentric and Western in its approach, viewing the 'Third World' or the Global South as beneficiaries of superior knowledge. Critical and third world approaches have emerged in strong dissent to these Eurocentric intellectual traditions, which have led to catastrophic economic consequences in poorer countries due to policy being applied in a historically and culturally neutral manner that does not suit the particular conditions of these countries. This paper attempts to shed light on the dire need to reform developmental economics in theory and practice, to account for culturally contextual approaches, indigenous knowledge, and depart from the neoclassical economic tradition of pursuing growth, GDP and profit in an unsustainable fashion.
\end{abstract}

Keywords: Development economics, Development Eurocentric, Economic growth

\section{INTRODUCTION}

Development economics is a branch of economics that focuses on improving fiscal, economic, and social conditions in developing countries (Kopp, 2019). Development economics considers factors such as health, education, working conditions, domestic and international policies, and market condition with a focus on improving conditions in the world's poorest countries (Kopp, 2019). Despite a purported focus on developing countries and their improvement, the foundations of development economics as a discipline emerged essentially from Western and Eurocentric perspectives, proposing homogenized models of development for all cultures and countries on the basis of the western ideal- for example, from the policies of mercantilism, and 


\section{International Journal of Social Science and Economic Research}

ISSN: $2455-8834$

Volume: 05, Issue: 06 "June 2020"

the linear growth model which was used to revitalize the European economy post the Second World War (Kopp, 2019).

Economists and theorists who are critical of these theoretical models argue that in the name of development, the rest of the world is undergoing submission to the global econo my and a kind of homogenisation of cultures as the western model of development based on economic growth, science, technology and bureaucratic systems is taken to be the norm for everywhere (Brohman, 1995; Mehmet, 1990). Postmodernism and relativism stress the diversity of cultures threatened by development and the lack of a common reference point informed by reason. Marxist and Realist analysis of economic and international power will see the discourse as a tool for dominant interests (Brohman, 1995). More modestly, if one sees development as much more than economic growth, the implied comparison between North and South as developed and notdeveloped may be deeply questioned along with the assumption that the North provides the goal or model for the South (Brohman, 1995; Mehmet, 1990). And at the most pragmatic level one can simply observe how often, even in terms of the standard goals of development aid, things go wrong.

Given their Western social science background, many development theorists across a range of disciplines have been preconditioned to look for parallels between the development history of the West and contemporary development in non-Western societies; as a result, the actual development experiences of different societies have been simplified and distorted (Brohman, 1995). Because of this, many analyses have been conceptually incapable of addressing the root causes of critical development problems in these societies (Brohman, 1995). There is a dire need for more regional contexts and historical and intellectual perspectives to be taken into account, divorced from Eurocentric contexts unmindful of post colonialism.

This paper will provide a critique of the Eurocentric theoretical foundations of development economics, and provide alternative critical perspectives in the field which account for the unique historical and cultural contexts of the third world and global south. The paper will pose recommendations for the future of development economics and policy institutions, to better tailor development theories and solutions to particular cultural contexts.

\section{BACKGROUND}

The prominent definitions of development in itself have been derived from Eurocentric traditions, and neoclassical economics. Given the prominence of economics within mainstream development theory, the generation of economic growth has usually been afforded a central place in development studies (Brohman, 1995; Dower, 1996). For most neoclassical economists and related development theorists, the concept of economic growth is neither culture-specific nor is it 


\section{International Journal of Social Science and Economic Research}

ISSN: $2455-8834$

Volume: 05, Issue: 06 "June 2020"

based on historically changing conditions. Instead, economic growth is subject to its own universal laws irrespective of the sociocultural or historical contexts within which it occurs (Dower, 1996).

Postwar developmentalism was a Euro-centric conception of development. It was an optimistic and axiomatic worldview, shaped, in part, by the success of European reconstruction under the Marshall Plan (Mehmet, 1990). Its central premise was the replicability of Western experience in post-colonial areas in what was termed the Third World ranked after the First (capitalist) and Second (socialist) Worlds (Mehmet, 1990). The basis of the optimistic Euro-centric conception of development was the belief in the universality of the "law" of development. According to this "law", there is only one, "universal reference" model of development. viz. Westernization, the logic of which is capitalism, and it occurs along a linear time-path and undergoes certain identifiable, predictable stages (Mehmet, 1990).

History (i.e. historical time) simply meant Western experience; thus, Euro-centric developmentalists constructed diffusionist models of Third World development predicated on the unstated expectation that the latter would follow the path travelled previously by the West (Mehmet, 1990; Dower, 1996). Therefore, the West could teach and the Third World should follow. This has continued as the critical assumption in the modernization school by the famous Rostowian Stages of Growth (Mehmet, 1990). The fundamentals of development economics that were applied to the 'Third World', were therefore steeped in colonial oppression. "Development economics" was originally invented in the west and then handed over to the south (Alvares, 2011; Browne, n.d). Its assumptions were the same as those undergirding the economic assumptions of the western economies (Alvares, 20111). The only difference was their rather uncavalier, unprincipled, irresponsible application to the countries of the south. The major "third world" development economists were all "first world" people: Bauer, Colin Clark, Albert O Hirschman, Arthur Lewis, Gunnar Myrdal, Paul Prebisch, Paul Rosentein-Rodan, Walt Rostow, Hans Singer, and Jan Tinbergen (Alvares, 2011). These came to dominate the thinking on economics and development (Alvares, 2011).

Therefore, the conceptualization of the third world as receivers of western aid and benefit of their industries, creates a binary in which the voices of the Global South are effectively seen as the 'other' and discounted (Browne, n.d). The following section of this paper will elaborate further on third world and postcolonial perspectives of development economics, and the disadvantages of continuing with the Eurocentric intellectual tradition as a universal model. 


\section{International Journal of Social Science and Economic Research}

ISSN: $2455-8834$

Volume: 05, Issue: 06 "June 2020"

\section{DISCUSSION}

Eurocentrism has impeded progress in development studies in both the North and South. In the North, it has impoverished development studies and related disciplines by blocking access to alternative concepts and indigenous sources of knowledge from the developing countries themselves (Brohman, 1995). In the South, it has perpetuated intellectual dependence on a restricted group of prestigious Western academic institutions that determine the subject matter and methods of research (Brohman, 1995; Alvares, 2011). Categories and concepts are borrowed which may have been useful and meaningful within their original Western contexts, but which lose much of their meaning and utility in the process of being transposed into Third World contexts (Alvares, 2011). Commonly, the Third World is relegated to the status of a residual category-a type of conceptual 'grab bag' for what remains after the important elements of development (characteristic of modern First World societies) have been accounted for (Brohman, 1995). This both obscures the real significance of developments in the South and conditions its inhabitants to accept the 'inevitability' of their inferior position, given the clear superiority of everything Western (Brohman, 1995).

Third World approaches to development economics have therefore emerged as a response to these impediments and exclusion of indigenous intellectual traditions and participations. Many Third World institutions bear little resemblance to and function quite differently from their First World counterparts (Brohman, 1995; Dower, 1996; Trainer, 2016). For example, the land, labour, credit and product markets of most developing countries normally do not obey the universal assumptions or formalised economic principles of neoclassical theory (Trainer, 2016). Such differences render many of the universal concepts and ready-made strategies of the mainstream development models inoperative. In most cases, if Western-style structures and institutions are to exist in Third World societies, they have to be artificially created and sustained (Brohman, 1995: Mehmet, 1990, Trainer, 2016).

This has led to situations wherein specific crises and scenarios in the global south have not been adequately addressed by Eurocentric models. Third world and critical approaches underscore the importance of cultural contextualization and real world understanding in the study of economics. Due to the essentially neoliberal framework of the Eurocentric development model, the inequality evident within the world economy is extreme (Trainer, 2016). The richest $20 \%$ of people are getting around $86 \%$ of world income, while the poorest $20 \%$ of people are getting only $1.3 \%$. About half the world's people have an income of under $\$ 2$ per day (Trainer, 2016).

Far from progressing towards "self-sustaining, economic growth" and prosperity, the Third World has fallen into such levels of debt that few would now hold any hope of repayment (Trainer, 2016). Meanwhile many Third World governments deprive their people and strip their 


\section{International Journal of Social Science and Economic Research}

ISSN: $2455-8834$

Volume: 05, Issue: 06 "June 2020"

forests more fiercely to raise the money to meet the debt repayments. The magnitude of the debt problem sets a major challenge to anyone who believes the conventional development strategy can lead the Third World to prosperity (Trainer, 2016).

A prime example of the manner in which the voices of the third world in developmental discourse has been drowned out is the coverage around the COVID-19 pandemic and economic revival (Parr, 2020). Media coverage has to a large extent focused on experiences of the United States and Europe (Parr, 2020). The frameworks developed to respond to the pandemic have also been US/Euro-centric, frequently inward-looking and isolationist, paying scant attention to expertise, knowledge, and capacities elsewhere (Parr, 2020). The experiences of other parts of the world, even when taken into account, often serve to cement prior prejudices (Parr, 2020).

Third world leaders and theorists have called for a global response to the pandemic that does not depend on 20th-century institutions as these institutions have been undermined and captured by interests of powerful countries and corporations (Parr, 2020). There is a need for a new order, based on "true principles of multilateralism," with countries of the South proactively creating new alliances (Parr, 2020).

\section{CONCLUSION}

In order to transcend the Eurocentrism that underlies the theory of development economics, and produce credible and meaningful work towards a non-Eurocentric social science framework, a firm prior decision or commitment to intellectual delinking from the existing theories and the corpus of Eurocentric and European social sciences is required at the level of each academic council or university (Alvares, 2011). Serious efforts must be made to discuss culture-rooted and culture-acceptable assumptions for research and methodology, methods that are in harmony with our cultural values, environment and all life. We must relink critically with indigenous intellectual traditions (Alvares, 2011).

Neoliberalism has especially been promoted by transnational financial capital and associated financial institutions, such as the World Bank and the IMF, which have succeeded in imposing a new development agenda on much of the South via SAPS and other forms of conditional lending (Mehmet, 1990; Dower, 1996; Brohman, 1995). In spite of their global scope and formally independent structures, these institutions are closely associated with the ideological and geopolitical interests of the Western powers, especially of the USA (Trainer, 2016; Alvares, 2011). There is a need for the United Nations and the various organizations under it to consider regional perspectives and un-learn the conventional Eurocentric conceptions of development that are couched within the language of economic growth. 
International Journal of Social Science and Economic Research

ISSN: $2455-8834$

Volume: 05, Issue: 06 "June 2020"

It is encouraging in this respect that the UNDP has recognized that the specific mix of macroeconomic policies to support human development and economic growth will vary from one country to the next, and depend on a variety of factors, including the structure of the economy, the level of financial and economic development, the nature of institutions (including financial institutions) and the relationship to the global economy (UNDP, 2013). The assumption that wealth will 'trickle down' from the richer to poorer countries must be rejected Conventional developmental economists typically enthuse about gains but ignore the losses (Trainer, 2016). It is not clear how big the net gains in income, employment and welfare have been but the above evidence on global poverty changes suggest that they have not been as spectacular as is commonly claimed, and that many have actually gone backwards (Trainer, 2016).

Alternative theories of development to the growth model must be considered. Social and ecological goals must take priority over economic goals. Development decisions must be based on considerations of social need, morality, justice, rights, tradition, social cohesion and ecological sustainability (Trainer, 2016). Governments must prioritise the building of the nonmonetary and non-market sector of the local economy. It is important to develop shared facilities, village commons, working bees, community workshops, committees, cooperatives, decisions by village assemblies, and to encourage giving and sharing, volunteering, helping, civic responsibility and social cohesion (Trainer, 2016). An acceptable approach to development has to be framed in terms of The Simpler Way; that is, focused on providing a high quality of life for all on only very low levels of production, consumption, resource use or GDP (Trainer, 2016).

Development economics must be grounded on the relevant history and culture. This would require a more institutional and historical approach, mobilising local values and cultures as potential sources of progress, not as "barriers" to development as Euro-centric theorists tended to presume (Alvares, 2011; Mehmet, 1990; Brohman, 1995). Instead of a "universal reference" model of Westernization, future students of development studies explicitly recognize cultural diversity, and, indeed, adopt a culture-specific approach to development, tailor-made to the specific situation of each society (Mehmet, 1990).

\section{REFERENCES}

Alvares, C, (2011), A Critique of Eurocentric Social Science and the Question of Alternatives, Economic and Political Weekly, Vol. 46, No. 22 (MAY 28-JUNE 3, 2011), pp. 72-81, https://www.jstor.org/stable/23018594?seq=1 
Brohman, J. (1995). Universalism, Eurocentrism, and Ideological Bias in Development Studies: From Modernisation to Neoliberalism. Third World Quarterly, 16(1), 121-140. Retrieved June 17, 2020, from www.jstor.org/stable/3992977

Browne, K, (n.d), 'Project on What "other" voices are out there to counter Eurocentric development?', https://www.mkgandhi.org/students/project1.htm

Dower N. (1996) Is the Idea of Development Eurocentric? In: Auty R.M., Toye J. (eds) Challenging the Orthodoxies. Palgrave Development Studies Series. Palgrave Macmillan, London

Kopp, C, (13 May 2019), 'Development Economics Definition', Investopedia, https://www.investopedia.com/terms/d/developmenteconomics.asp\#: :text=Development $\% 20$ economics $\% 20$ is $\% 20 \mathrm{a} \% 20 \mathrm{branch}, \mathrm{a} \% 20$ focus $\%$ 20on\%20improving $\% 20$ conditions

Mehmet, O. (1990), "Alternative Concepts Of Development: A Critique Of Euro-Centric Theorizing", Humanomics, Vol. 6 No. 3, pp. 55-67. https://doi.org/10.1108/eb006108

Parr, SP, (6 June 2020), 'Pandemic Discourses - A Global Contagion Demands Global Perspectives', Developing Economics, https://developingeconomics.org/2020/06/06/anintroduction-pandemic-discourses/

Trainer, T, (5 November 2016), 'Scrap The Conventional Model Of Third World "Development', Resilience, https://www.resilience.org/stories/2016-11-05/scrap-theconventional-model-of-third-world-development/

UNDP, (2013), 'Issues For A Global Human Development Agenda', United Nations Development Programme Human Development Report Office Occasional Paper Series. 